\title{
Sistem Monitoring Suhu pada Aplikasi Absensi Pegawai untuk Deteksi Dini COVID-19
}

\author{
Mohammad Robihul Mufid \\ Jurusan Teknik Informatika \\ Politeknik Elektronika Negeri Surabaya \\ Surabaya, Indonesia \\ mufid@pens.ac.id \\ Arif Basofi \\ Jurusan Teknik Informatika \\ Politeknik Elektronika Negeri Surabaya \\ Surabaya, Indonesia \\ ariv@pens.ac.id
}

\author{
Saniyatul Mawaddah \\ Jurusan Teknik Informatika \\ Politeknik Elektronika Negeri Surabaya \\ Surabaya, Indonesia \\ saniyatul@pens.ac.id \\ Mochammad Jauhar Ulul Albab \\ Jurusan Teknik Informatika \\ Politeknik Elektronika Negeri Surabaya \\ Surabaya, Indonesia \\ majauhar@it.student.pens.ac.id
}

\author{
Darmawan Aditama \\ Jurusan Multimedia Broadcasting \\ Politeknik Elektronika Negeri Surabaya \\ Surabaya, Indonesia \\ aditama@pens.ac.id \\ Agung Fiyanto \\ Jurusan Teknik Informatika \\ Politeknik Elektronika Negeri Surabaya \\ Surabaya, Indonesia \\ fiyan@it.student.pens.ac.id
}

\begin{abstract}
Positive confirmed cases of COVID-19 in office clusters are increasing. This happened as the government allowed the re-opening of several companies to help drive the economy. Several health protocols have been developed by the Ministry of Health. However, in the implementation that is carried out in offices, the spread of COVID-19 cannot be completely prevented. One way to prevent the spread of COVID-19 in office clusters is to ensure that employees who arrive are healthy. To ensure that employees who come are likely to be infected with the COVID-19 virus or not, a fast and reliable early detection system for COVID-19 is needed. In this study, a COVID-19 early detection system was proposed by combining a temperature monitoring system and an expert system that was implemented in the employee attendance system. Every employee who wants to enter, is required to have presence on the system. Before the system records the employee's attendance, the system will process the employee's temperature information from the temperature monitoring system and the expert system to detect whether the employee may have COVID-19 or not. The results of this early detection can be a recommendation to the company to determine whether an employee can continue to work in the office or must work at home.
\end{abstract}

Keywords - COVID-19 detection; temperature monitoring system; expert system; employee attendance system.

Abstrak- Kasus terkonfirmasi positif COVID-19 pada
klaster perkantoran semakin meningkat. Hal ini terjadi seiring
dengan diizinkannya kembali pembukaan beberapa
perusahaan oleh pemerintah untuk membantu menggerakkan
ekonomi. Beberapa protokol kesehatan telah dibuat oleh
Kementrian Kesehatan. Akan tetapi pada penerapan yang
dilakukan di perkantoran, penyebaran COVID-19 belum bisa
dicegah sepenuhnya. Salah satu cara agar penyebaran COVID-
19 pada klaster perkantoran bisa dicegah adalah memastikan
karyawan yang datang dalam kondisi yang sehat. Untuk
memastikan karyawan yang datang berkemungkinan terinfeksi
virus COVID-19 atau tidak, diperlukan sebuah sistem deteksi
dini COVID-19 yang cepat dan handal. Dalam penelitian ini,
diajukan sebuah sistem deteksi dini COVID-19 dengan
memadukan sistem monitoring suhu dan sistem pakar yang
diimplementasikan pada sistem absensi karyawan. Setiap
karyawan yang hendak masuk, diwajibkan melakukan presensi
pada sistem. Sebelum sistem merekam kehadiran karyawan
tersebut, sistem akan memproses informasi suhu karyawan

dari sistem monitoring suhu dan sistem pakar untuk mendeteksi apakah karyawan tersebut berkemungkinan terkonfirmasi COVID-19 atau tidak. Hasil dari deteksi dini ini dapat menjadi rekomendasi kepada perusahaan untuk menetukan seorang karyawan boleh tetap bekerja di kantor atau harus bekerja di rumah.

Keywords-Deteksi COVID-19; sistem monitoring suhu; sistem pakar; sistem absensi karyawan.

\section{PENDAHULUAN}

Di era new normal ini, pemerintah pada beberapa daerah telah mengizinkan dibukanya perkantoran di tengah pandemi COVID-19, dengan tujuan membantu menggerakkan ekonomi. Kerena beroperasinya beberapa perusahaan ini maka menyebabkan penyebaran COVID-19 merebak kembali diberbagai klaster. Salah satu yang menjadi sorotan adalah pada klaster perkantoran. Penerapan protokol pencegahan sebenarnya sudah dibuat oleh kementerian kesehatan setidaknya ada 23 poin yang harus dipenuhi untuk mencegah proses penyebaran COVID-19 di perkantoran. Akan tetapi memang pada kenyataannya proses penyebaran COVID-19 di klaster perkanotran ini masih tinggi $[1,2]$.

Setidaknya ada tiga faktor yang menjadi penyebab penularan COVID-19 pada klaster perkantoran. Pertama adalah karena faktor penyakit COVID-19 itu sendiri. Belum lama ini organisasi kesehatan dunia (WHO) menyatakan, COVID-19 bisa menular melalui udara (airborne), ini berarti penularan antar rekan kerja menjadi lebih mudah. Kedua karena faktor kepatuhan orang itu sendiri terhadap protokol kesehatan yang diterapkan. Dengan menjaga jarak dan menghindari keramaian adalah merupakan cara yang paling efektif agar proses penyebaran COVID-19 bisa dikurangi sedikit mungkin. Tapi dalam melakukan interaksi kerja diperkantoran menjaga jarak merupakan hal yang cukup sulit dihindari. Faktor yang terakhir adalah mengenai kebijakan. Ini dikarenakan aturan yang dibuat masih belum menyeluruh dan masih belum mencegah sepenuhnya penyebaran COVID$19[3,4,5]$.

Salah satu cara agar penyebaran COVID-19 pada klaster perkantoran bisa dicegah selain memastikan ruangan yang harus bersih dan terbebas dari virus adalah setiap pegawai wajib melewati prosedur standar adaptasi kebiasaan baru. Dimana hal tersebut meliputi mencuci tangan, memakai masker, cek suhu tubuh, dan perusahaan harus memastikan 
karyawan dalam kondisi yang sehat ketika datang ke kantor. Dalam mengetahui karyawan yang datang berkemungkinan terinfeksi virus COVID-19 atau tidak, diperlukan sebuah sistem deteksi dini COVID-19 yang cepat dan handal [6]. Pada saat ini untuk melakukan deteksi COVID-19 pada diri seseorang dilakukan dengan 2 tes, yaitu tes Polymerase Chain Reaction (PCR) dan rapid test (rapid test antibodi dan swab antigen). Dari kedua tes tersebut yang mempunyai akurasi yang paling baik adalah tes dengan menggunakan metode $P C R$, karena didalam metode $P C R$ dilakukan dengan cara mencari jejak genetik virus dari sampel yang diambil dari hidung dan tenggorokan. Akan tetapi tes dengan menggunakan metode $P C R$ ini membutuhkan biaya yang tinggi dan waktu yang cukup lama dibandingkan dengan rapid test. Kebanyakan pada saat ini, untuk menentukan apakah seseorang menderita penyakit COVID-19 adalah dengan cara mendeteksi suhu seseorang sebagai indikator awal apakah orang tersebut dalam kondisi sehat atau tidak [7].

Dalam rangka menyelesaikan kasus COVID-19 ini, sebenarnya sudah ada beberapa penelitian yang dilakukan diantaranya yaitu penelitian oleh Raju Vaishya et al. [8] yang melakukan peninjauan pada peran teknologi Artificial Intelligence (AI) dalam menangani kasus pandemi COVID19. Metode yang dilakukan dalam penelitiannya adalah menganalisa jurnal-jurnal yang terdapat pada penyedia jurnal seperti Scpous, Pubmed, dan Google Scholar mengenai teknologi $A I$ untuk COVID-19. Hasil yang didapatkan adalah teknologi $A I$ mempunyai manfaat dalam melakukan deteksi dan melakukan prediksi tentang penyebaran COVID-19 yang akan terjadi selanjutnya. Selain itu $A I$ juga digunakan untuk melakukan pelacakan terhadap data pasien COVID-19 baik yang pasien baru dikonfirmasi tekena COVID-19, pasien yang sembuh, ataupun pasien yang sudah meninggal.

Salah satu penerapan teknologi $A I$ untuk penanganan COVID-19 ini telah dilakukan oleh W. Arshad et al. [9] dalam malakukan diagnosa COVID-19 yang diterapkan pada peralatan CT scan atau disebut COVIDC. Dimana sistem ini menggunakan metode Support Vector Machine (SVM) dan Random Forest untuk mengatasi kelangkaan data dalam mendiagnosis COVID-19. Hasil dari pengujian COVIDC dibandingkan dengan metode deteksi COVID-19 yang lainnya didapatkan hasil yang lebih efektik untuk melakukan diagnosa.

Selain itu penerapan $A I$ juga diusulkan oleh Khusnul Khotimah et al [10] yang menggunakan metode sistem pakar untuk melakukan deteksi dini COVID-19 berbasis aplikasi Android. Sistem yang diusulkan juga menyediakan sistem mitigasi untuk mencegah bertambahnya kasus COVID-19 di Indonesia. Dalam pembuatan sistem mitigasi pada penelitian ini diambil dari data yang tersedia pada situs gugus tugas COVID-19 Indonesia. Dari berbagai pengujian yang dilakukan terhadap sistem yang dilakukan dengan beberapa skenario, dapat disimpulkan bahwa sistem pakar cukup efektif untuk digunakan sebagai sistem deteksi dan mitigasi dini COVID-19.

Penelitian yang serupa mengenai pengaplikasian teknologi untuk menyelesaikan kasus COVID-19 juga dilakukan oleh R. P. Singh et al. [11]. Penelitian yang dilakukan adalah menganalisa bagaimana peran dari teknologi Internet of Things (IoT) untuk mengatasi COVID19. Hasil proses analisa dari penelitian yang dilakukan terhadap 12 aplikasi yang menggunakan IoT untuk COVID19 dapat disimpulkan bahwa dengan teknologi IoT dapat membantu melakukan identifikasi dini mengenai gejalagejala COVID-19 dan dapat digunakan untuk memberikan penanganan dan pengobatan yang lebih baik dan lebih cepat. Serta dengan teknologi IoT dapat digunakan untuk membuat sistem manajemen yang lebih baik.

Berkaitan dengan teknologi IoT ini M. N. Mohammed juga mengusulkan sebuah penelitian untuk merancang sebuah helmet yang digunakan untuk mendeteksi demam sebagai gejala awal yang ditimbulkan penyakit COVID-19. Selain dilengkapi dengan kamera thermal, teknologi helmet ini juga dilengkapi dengan teknologi pengenalan wajah dan sebuah sistem untuk menampilkan informasi suhu dari pejalan kaki agar bisa dilihat oleh orang lain, sehingga orang lain bisa lebih waspada jika suhu dari pemakai helmet tersebut tinggi [12].

Dalam penelitian ini, diajukan sebuah sistem deteksi dini COVID-19 dengan memadukan sistem monitoring suhu yang merupakan penerapan dari teknologi IoT dan sistem pakar sebagai penerapan dari teknologi $A I$ untuk diimplementasikan pada sebuah sistem absensi karyawan. Setiap karyawan yang hendak masuk akan diwajibkan melakukan presensi pada sistem absensi karyawan. Kerena dengan melakukan presensi, sistem akan mendeteksi terlebih dahulu apakah karyawan tersebut berkemungkinan terkonfirmasi COVID-19 atau tidak dengan melihat suhu tubuh dan analisa sistem pakar dari jawaban yang diinputkan oleh karyawan tersebut. Sehingga dengan memastikan kondisi dari masing-masing karyawan setiap datang ke kantor, maka penyebaran kasus COVID-19 di klaster perkantoran akan bisa dicegah.

\section{METODE PENELITIAN}

Penelitian mengenai pembuatan sistem monitoring suhu pada aplikasi absensi pegawai untuk deteksi dini COVID-19 akan dibagi menjadi beberapa tahapan yaitu pembutan konsep, perancangan sistem, implementasi sistem, pengujian sistem dan analisa sistem. Mekanisme pekerjaan yang akan dikerjakan pada penelitian yang diusulkan ini seperti pada gambar 1 .

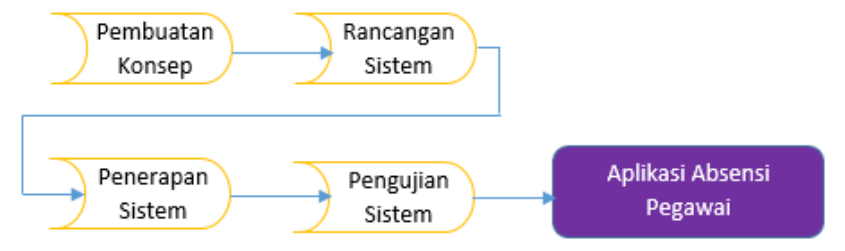

Gambar. 1.Diagram urutan pekerjaan pada penelitian yang diusulkan

\section{A. Pembuatan konsep}

Pada tahap ini, rancangan dan tujuan dari pembuatan penelitian ini mulai di buat. Dimana tujuan awal dari penelitian ini adalah untuk membuat suatu sistem aplikasi absensi yang bisa mempunyai manfaat lain selain untuk melakukan pencatatan data absensi pegawai, tetapi juga bisa digunakan untuk melakukan deteksi dini COVID-19 pada pegawai yang bekerja di kantor. Konsep dari sistem monitoring suhu pada aplikasi absensi pegawai ini adalah dengan membuat sistem deteksi suhu seseorang yang dibuat dengan menggunakan sensor suhu MLX90614. Sensor ini menyediakan pancaran inframerah yang diubah menjadi arus listrik yang akan menimbulkan tegangan dan kemudian 
diubah menjadi sinyal digital oleh sensor. Sedangkan untuk microcontroller yang digunakan dalam penelitian ini menggunakan Arduino Nano V3 sebagai tempat mengolah data sensor, yang dikombinasikan dengan modul wifi untuk melakukan pengiriman data ke server. Setelah data disimpan dan diolah didalam server, maka data sensor suhu tersebut bisa digunakan untuk indikator dalam mendeteksi dini COVID-19 dengan mengkombinasikan indikator-indikator lain dengan menggunakan sistem pakar. Untuk skenario peletakan sistem monitoring suhu ini akan ditempatkan pada pintu masuk kantor, sehingga seoarang pegawai dapat melakukan pengambilan suhu dan absensi terlebih dahulu sebelum memasuki kantor. Sehingga bisa mencegah dan mengurasi resiko akan adanya korban yang terkena penyakit COVID-19.

\section{B. Rancangan Sistem}

Pada bagian ini, akan dijelaskan mengenai bagaimana rancangan-rancangan dari sistem monitoring suhu pada aplikasi absensi pegawai untuk deteksi COVID-19 ini akan dibuat. Pada gambar 2 dijelaskan mengenai rancangan sistem dari penelitian ini dilakukan. Dimana proses pembuatan dari sistem ini akan dibagi menjadi 2 tahapan, yaitu tahapan dalam sistem deteksi suhu dan absensi pegawai, dan tahapan dalam pembuatan pembuatan sistem mitigasi dan monitoring absensi pegawai.

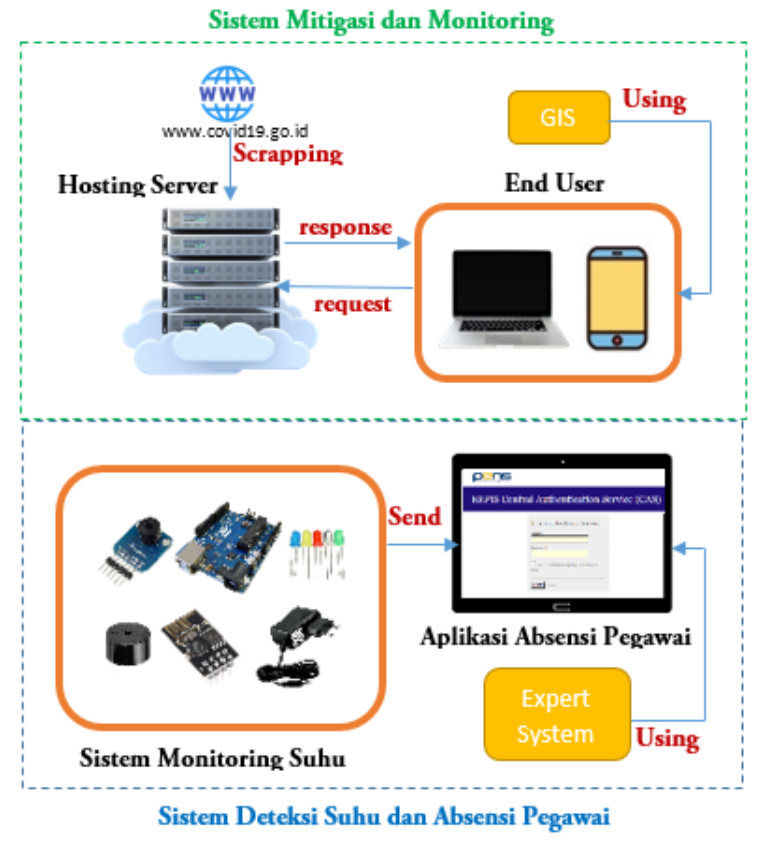

Gambar. 2.Rancangan penelitian yang diusulkan

Tahapan 1 : Sistem deteksi suhu dan absensi pegawai

Tujuan dari tahapan ini adalah bertujuan untuk menjelaskan bagaimana sistem bekerja untuk melakukan deteksi suhu dan melakukan sistem absensi pegawai untuk melakukan deteksi dini penyakit COVID-19 dengan cara mendeteksi suhu sesorang ketika melakukan absensi apakah orang tersebut mengalami demam atau tidak. Alasan pentingnya untuk mendeteksi suhu seseorang adalah karena dengan suhu kita bisa menganalisa kondisi kesehatan seseorang apakah orang itu sedang dalam kondisi sehat atau tidak. Suhu seseorang dikatakan normal adalah jika suhu tubuhnya diantara 36,5 - 37,2 derajat celcius. Jika suhu tubuh seseorang kurang dari 35 derajat celcius, maka orang tersebut akan mengalami hipotermia. Sedangkan untuk demam adalah jika suhu tubuh seseorang tersebut berada diatas 37,5 derajat celcius. Dan jika suhu melebihi 40 derajat celcius, maka orang tersebut akan mengalami hipertermia. Orang yang mengalami hipotermia bisa mengancam jiwa jika tidak segera dilakukan pertolongan, karena hipotermia bisa memperlambat sistem kerja saraf yang menyebabkan kegagalan dari fungsi organ. Begitu pula orang yang mengalami hipertermia juga harus segera ditangani, karena bisa menyebabka heat stroke, heat stress, heat fatigue, dan bahkan kecacatan atau kematian. Berbeda dengan demam yang disebabkan karena adanya reaksi antara sistem imun untuk melawan bakteri, virus, jamur, atau disebabkan karena parasit penyebab penyakit. Demam yang dikarenakan virus biasanya akan sembuh dengan sendirinya karena adanya reaksi dari sistem imun. Akan tetapi karena demam merupakan gejala dari berbagai macam kondisi penyakit maka demam ini juga harus diwaspadai. Salah satu penyakit yang memilik gejala demam adalah para penderita penyakit COVID-19. Sehingga diperlukan suatu sistem untuk memantau suhu sesorang untuk memeriksa apakah kondisi seseorang tersebut dalam kondisi sehat atau tidak.

Gambar 3 merupakan sebuah sistem untuk memantau suhu seseorang dan sebuah aplikasi absensi pegawai. Sistem monitoring suhu ini akan diletakkan pada pintu masuk kantor sebelum pegawai melakukan absensi pegawai dari perangkat end user masing-masing. Perangkat sistem monitoring suhu akan mengirimkan data suhu ke aplikasi absensi pegawai melalui modul wifi yang tertanam pada sistem tersebut. Kemudian ketika user melakukan absensi dengan cara melakukan login dan menjawab beberapa pertanyaan yang digunakan sebagai indikator untuk menganalisa hasil kondisi seseorang dengan menggunakan sistem pakar. Dimana data dari absensi pegawai itu akan dikirimkan ke hosting server untuk server untuk disimpan dan dikelola.

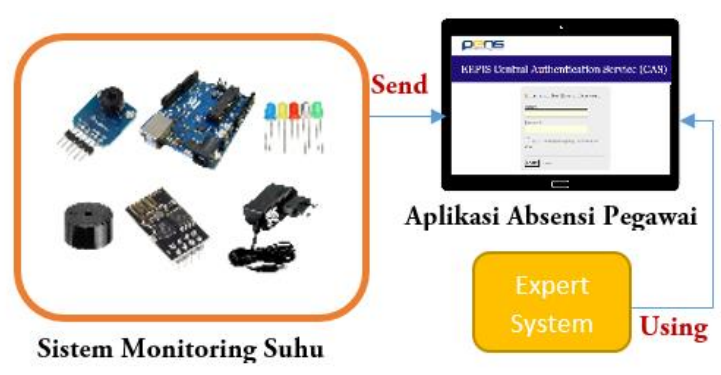

Gambar. 3.Sistem deteksi suhu dan absensi pegawai

Gambar 4 merupakan komponen-komponen yang terdapat pada sistem monitoring suhu. Dimana dalam sistem ini terdiri dari komponen arduino nano V3 yang digunakan sebagai microcontroller, led indicator sebagai penanda adanya tegangan tinggi, sensor MLX90614 untuk mendeteksi suhu, buzzer sebagai indikator audio, adapter power sebagai sumber energi, dan wifi module untuk mengirimkan data sensor ke aplikasi sistem absensi pegawai. Aplikasi sistem absensi pegawai ini selain digunakan untuk merekam data kehadiran, tetapi juga menyediakan fitur sistem pakar yang ditampilkan dalam bentuk pertanyaan-pertanyaan untuk mendeteksi dini COVID-19 dengan ditambahkan data suhu sebagai indikator hasil analisanya. Tabel 1 merupakan pertanyaan-pertanyaan yang digunakan sebagai indikator dalam proses pembuatan sistem pakar deteksi dini COVID- 
19. Setiap indikator pertanyaan mempunyai bobot yang digunakan sebagai bahan analisa.

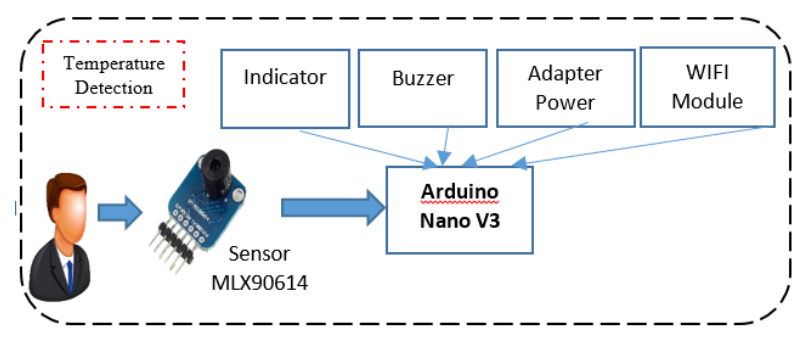

Gambar. 4.Komponen sistem monitoring suhu

TABEL I. INDIKATOR PERTANYAAN SISTEM PAKAR

\begin{tabular}{|c|c|c|c|}
\hline \multirow{2}{*}{$\begin{array}{l}\text { Indika } \\
\text { tor }\end{array}$} & \multirow{2}{*}{ Pertanyaan pada Aplikasi } & \multicolumn{2}{|c|}{ Bobot Jawaban } \\
\hline & & iya & tidak \\
\hline $\mathrm{I} 1$ & $\begin{array}{c}\text { Apakah anda kesulitan } \\
\text { bernapas yang parah (bernapas } \\
\text { sangat cepat atau berbicara } \\
\text { dalam satu kata)? }\end{array}$ & 6 & 0 \\
\hline $\mathrm{I} 2$ & $\begin{array}{c}\text { Apakah anda nyeri dada yang } \\
\text { parah? }\end{array}$ & 6 & 0 \\
\hline $\mathrm{I} 3$ & $\begin{array}{c}\text { Apakah anda sulit untuk } \\
\text { bangun? }\end{array}$ & 6 & 0 \\
\hline I4 & Apakah anda merasa bingung? & 6 & 0 \\
\hline I5 & $\begin{array}{l}\text { Apakah anda mengalami } \\
\text { penurunan kesadaran? }\end{array}$ & 6 & 0 \\
\hline I6 & $\begin{array}{c}\text { Apakah anda sesak napas saat } \\
\text { istirahat? }\end{array}$ & 6 & 0 \\
\hline I7 & $\begin{array}{c}\text { Apakah anda mengalami } \\
\text { ketidakmampuan untuk } \\
\text { berbaring karena kesulitan } \\
\text { bernapas? }\end{array}$ & 6 & 0 \\
\hline I8 & $\begin{array}{l}\text { Apakah kondisi kesehatan } \\
\text { kronis Anda semakin parah } \\
\text { karena kesulitan bernapas? }\end{array}$ & 6 & 0 \\
\hline I9 & $\begin{array}{l}\text { Apakah anda demam (Dari } \\
\text { Sensor Suhu)? }\end{array}$ & 1 & 0 \\
\hline $\mathrm{I} 10$ & Apakah anda batuk? & 1 & 0 \\
\hline I11 & Apakah anda flu? & 1 & 0 \\
\hline $\mathrm{I} 12$ & $\begin{array}{l}\text { Apakah anda sakit } \\
\text { tenggorokan? }\end{array}$ & 1 & 0 \\
\hline I13 & $\begin{array}{c}\text { Apakah anda mengalami gejala } \\
\text { yang muncul setelah } \\
\text { bepergian? }\end{array}$ & 5 & 0 \\
\hline I14 & $\begin{array}{c}\text { Apakah anda pernah } \\
\text { memegang pasien COVID-19? }\end{array}$ & 5 & 0 \\
\hline $\mathrm{I} 15$ & $\begin{array}{l}\text { Apakah anda pernah } \\
\text { melakukan kontak fisik dengan } \\
\text { pasien COVID-19? }\end{array}$ & 5 & 0 \\
\hline I16 & $\begin{array}{l}\text { Apakah anda tidak merasakan } \\
\text { gejala apapun? }\end{array}$ & 0 & 0 \\
\hline
\end{tabular}

TABEL II. ANALISA DARI TOTAL BOBOT JAWABAN

\begin{tabular}{|c|c|}
\hline Analisa Resiko & Total Bobot Jawaban \\
\hline $\begin{array}{c}\text { Kondisi pegawai beresiko } \\
\text { rendah untuk terkena COVID- } \\
19\end{array}$ & $0-1$ \\
\hline $\begin{array}{c}\text { Kondisi pegawai beresiko } \\
\text { sedang untuk terkena COVID- } \\
19\end{array}$ & $2-4$ \\
\hline $\begin{array}{c}\text { Kondisi pegawai beresiko } \\
\text { tinggi untuk terkena COVID- } \\
19\end{array}$ & $>5$ \\
\hline
\end{tabular}

Tahapan 2 : Sistem mitigasi dan monitoring
Pada tahapan 2 ini bertujuan untuk membuat rancangan dari bagaimana sistem mitigasi dan monitoring akan dibuat. Gambar 5 merupakan rancangan dari sistem tentang mitigasi COVID-19 dan monitoring kondisi data pegawai yang semuanya tersimpan dalam hosting server. Sistem mitigasi dari penelitian ini adalah berisi tentang data-data penyebaran dari COVID-19 dan berita-berita terbaru mengenai kasus COVID-19 yang semua datanya diambil secara web scrapiing dari situs https://covid19.go.id/ sehingga data akan bisa diperbaruhi secara otomatis. Selain fitur mitigasi, pada penelitian ini juga disediakan fitur untuk monitoring data hasil absensi dan kondisi dari para pegawai. Sehingga bisa diketahui mana pegawai yang sehat dan pegawai yang kurang sehat. Sehingga bisa mengambil keputusan yang tepat untuk menerapkan kebijakan.

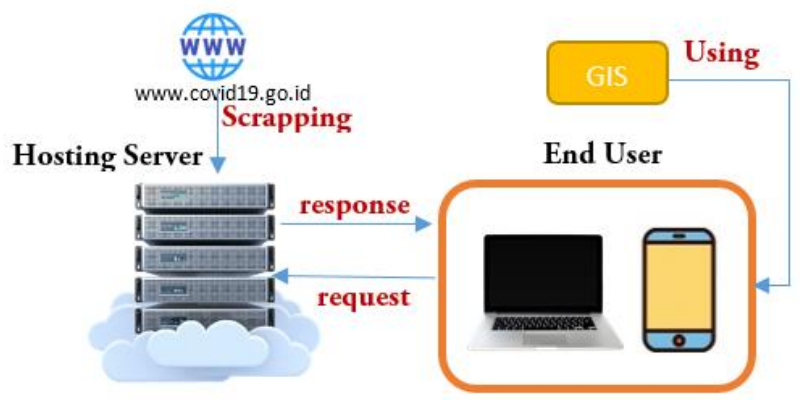

Gambar. 5.Rancangan sitem mitigasi dan monitoring

Gambar 6 merupakan sebuah tahapan dari proses yang dilakukan dalam melakukan web scrapping pada situs https://covid19.go.id/ yang dimulai dari tahapan url request yang bertujuan untuk melakukan permintaan url situs yang dituju untuk dilakukan web scrapping. Kemudian dilanjutkan proses penyimpanan, pengolahan, dan ekstraksi data di server. Sehingga hasil dari proses pengolahan data diserver tersebut nanti akan bisa dikirim dan ditampilkan pada perangkat end user.

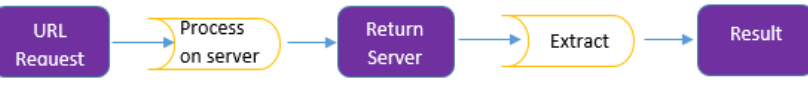

Gambar. 6.Alur dari web scrapping

\section{Penerapan Sistem}

Pada tahapan ini proses penerapan dari rancanganrancangan sistem yang dibuat mulai dilakukan. Dimana penerapan dari rancangan sistem ini akan dibagi menjadi 3 tahapan secara umum. Tahapan yang pertama yaitu implementasi pengujian pada sensor perangkat keras (sistem monitoring suhu) dan sistem aplikasi absensi pegawai. Tahapan yang kedua adalah penerapan dari rancangan sistem untuk diterapkan pada aplikasi yang ada di server. Dan yang paling terakhir adalah penerapan rancangan sistem untuk diterapkan pada perangkat end user yang bisa ditampilkan dalam bentuk aplikasi andorid dan website.

\section{Pengujian Sistem}

Dalam pengujian sistem yang dilakukan pada penelitian ini akan dibagai menjadi beberapa skenario. Skenario yang pertama adalah pengujian sistem dengan menggunakan umpan balik kepada pengguna dengan cara membuat pertanyaaan-pertanyaan kuisioner untuk mengetahui puas atau tidaknya responden terhadap sistem 
yang dibuat. Skenario kedua adalah dengan cara membuat pengujian terhadap fitur-fitur yang sudah dibuat dengan cara skenario-skenario pengujian untuk dilakukan user terhadap fitur yang tersedia apakah sudah bisa berjalan dengan baik atau tidak. Dan skenario pengujian terakhir adalah dengan cara membuat validasi sistem.

\section{HASIL DAN PEMBAHASAN}

Proses implementasi dan pengujian terhadap sistem akan dibahas pada bagian ini. Dimana pada penelitian ini sistem yang akan diterapkan akan dibagi menjadi beberapa bagian perangkat keras, yaitu sensor monitoring suhu dan sistem presensi, serta bagian perangkat lunak yang digunakan untuk sistem mitigasi dan monitoring yaitu aplikasi server dan aplikasi klien. Sedangkan untuk mellihat hasil performa dari sistem yang dibuat akan dilakukan menjadi beberapa skenario pengujian yang terbagi dalam beberapa skema pengujian yaitu pengujian dengan pembuatan pertanyaanpertanyaan mengenai kepuasan user, skema pengujian terhadap tugas-tugas tertentu, dan skema pengujian tentang validasi dari sistem yang dibuat.

\section{A. Pembuatan Perangkat keras (sistem monitoring suhu dan sistem aplikasi absensi pegawai)}

Dalam melakukan pembuatan perangkat keras ini, akan dibagi menjadi dua sistem yaitu sistem yang digunakan untuk memantau suhu tubuh karyawan dan sistem untuk absensi karyawan. Gambar 7 menunjukkan peralatan sensor perangkat keras yang dirangkai dan ditempatkan dalam sebuah box yang nantinya akan diletakkan di pintu masuk kantor. Hardware sensor yang digunakan pada penelitian adalah sensor jenis MLX90614, sensor tersebut digunakan untuk mendeteksi suhu. Sedangkan microcontroller yang digunakan adalah Arduino nano V3, dan untuk mengirimkan data ke aplikasi server pada penelitian ini menggunakan modul wifi, serta baterai untuk daya listrik dalam menjalankan microcontroller. Sedangkan untuk pembuatan sistem absensi karyawan pada penelitian ini diterapkan dengan menggunakan perangkat tablet atau smartphone. Untuk mencegah penyebaran COVID-19 dan terjaganya peralatan sensor dan tablet tetap steril, maka disediakan hand sanitizer yang dapat digunakan sebelum melakukan absensi.

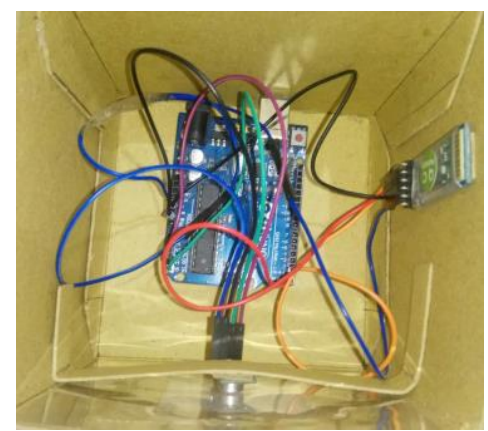

Gambar. 7.Perangkat keras sistem monitoring suhu

Untuk melihat bagaimana sistem yang dibangun bekerja, perlu dilakukan pengujian system. Salah satunya dengan memperagakan proses absensi sedang berlangsung. Gambar 8 memperlihatkan proses pengujian kerja dari sistem absensi karyawan yang dibuat. Pengguna melakukan pengukuran suhu untuk melihat suhu tubuh dan tercatat melalui sistem aplikasi sebelum lanjut login ke sistem absensi. Setelah pengguna melakukan pengecekan suhu tubuh, pengguna dapat melakukan pencatatan kehadiran dengan login ke sistem absensi menggunakan akun email pribadi yang tercatat pada database absensi.

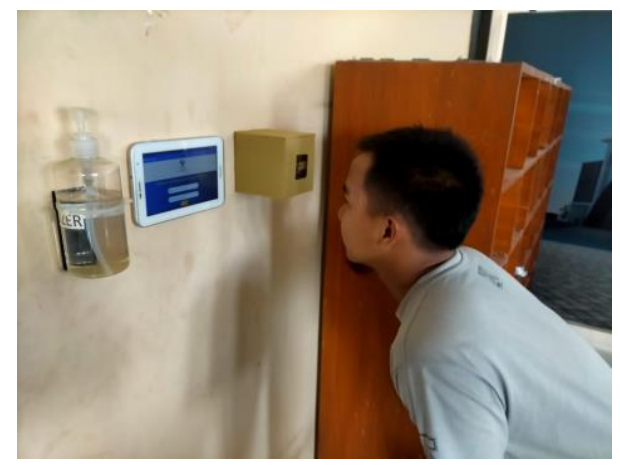

Gambar. 8.Proses deteksi suhu karyawan pada sistem absensi

Sistem absensi yang dilengkapi sistem pakar digunakan untuk mengkatagorikan suhu pengguna, apakah suhu pengguna termasuk dalam kategori terpapar oleh COVID-19 atau suhu pengguna masih dalam batas wajar. Gambar 9 menunjukkan sistem pakar sedang berjalan pada sistem absensi setelah pengguna melakukan proses login. Kemudian pengguna diharuskan menjawab beberapa pertanyaan yang hasil jawabannya diolah untuk digunakan oleh sistem pakar dalam melakukan deteksi dini penyakit COVID-19. Selanjutnya data karyawan yang sudah melakukan absensi dan menjawab pertanyaan sistem pakar kemudian dikirim dan diolah diserver yang nantinya bisa digunakan untuk sistem monitoring di aplikasi client.

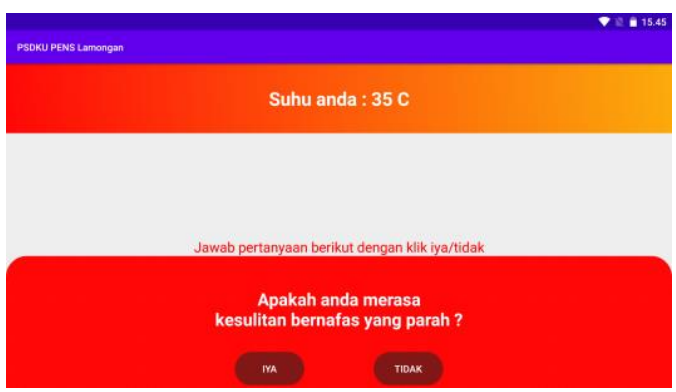

Gambar. 9. User interface sistem pakar pada sistem absensi karyawan

\section{B. Pembuatan perangkat lunak (aplikasi server dan aplikasi client)}

Perangkat lunak yang akan dibuat pada penelitian ini akan dibagi menjadi 2 aplikasi, yaitu aplikasi yang digunakan untuk server dan aplikasi yang digunakan untuk client. Pada tahapan implementasi system, penggunaan platform website dipilih untuk pengembangan aplikasi server dari penelitian sistem monitoring suhu untuk absensi karyawan. Tampilan menu utama dari website yang digunakan pada server penelitian ini seperti terlihat pada gambar 10. Pada tampilan utama dari website ini terdapat panel navigasi yang memudahkan admin untuk melihat jumlah dosen, jumlah mahasiswa, jumlah admin, dan jumlah user yang hadir (melakukan absensi). Ketika user login dengan user admin, maka akan memiliki hak akses untuk memanipulasi semua data. 


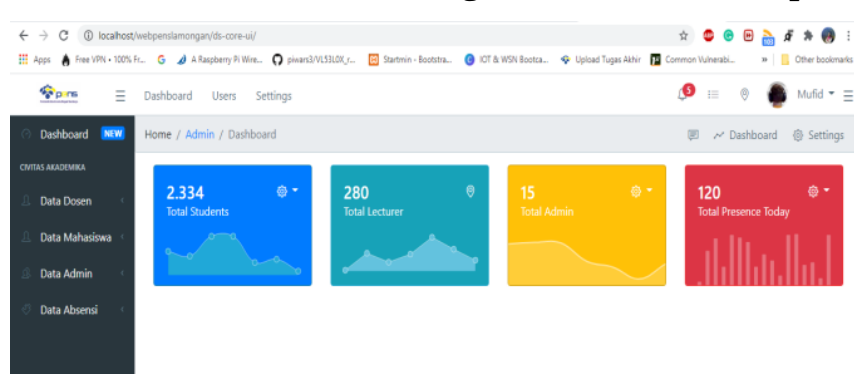

Gambar. 10.User interface dari sistem yang ada di server

Pada gambar 11 menunjukkan contoh hasil dari pengambilan data dari database yang tersedia di server. Data dari tabel tersebut kemudian diubah menjadi bentuk data JSON sehingga nantinya dapat diakses dan digunakan oleh aplikasi client dalam bentuk aplikasi android. Perubahan dalam bentuk data JSON ini dilakukan agar dapat mempermudah dalam melakukan proses pengiriman dan pertukaran data. Hal ini dikarenakn JSON memiliki format data yang sederhana, ringan, dan bisa dilakukan dengan domain yang berbeda.

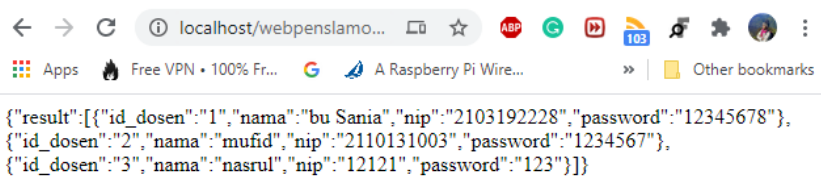

Gambar. 11.Tampilan data dari web service dalam bentuk JSON

Penelitian ini menggunakan platform android sebagai penerapan system yang ada pada sisi client [13]. Gambar 12 merupakan tampilan dari user interface yang ada pada aplikasi android. Didalam aplikasi ini terdiri dari berbagai macam menu yang tujuannya untuk melakukan monitoring dan mitigasi COVID-19. Terdapat menu COVID-19 yang berguna untuk memberikan informasi dan perkembangan terbaru dari kasus COVID-19 yang ada di Indonesia.

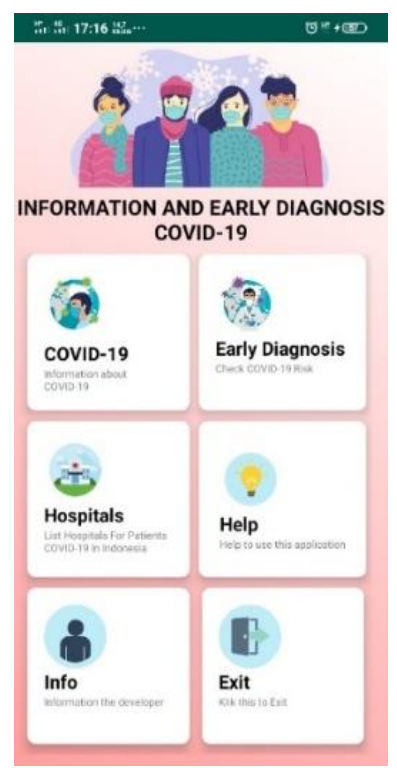

Gambar. 12. Tampilan Menu Utama

Gambar 13 merupakan tampilan berita yang menyampaikan informasi mengenai perkembangan COVID19. Peneliti juga menambahkan fitur berita dan informasi penanggunalangan COVID-19 beserta daftar rumah sakit yang ditunjuk pemerintah sebagai rumah sakit yang menangani kasus COVID-19 di Indonesia. Fitur tersebut dapat diakses kapan saja oleh pengguna, seperti yang terlihat pada gambar 13. Informasi yang disediakan oleh peneliti untuk pengguna diambil melalui proses web scrapping yang diproleh dari portal satgas penanganan COVID-19 di Indonesia (https://COVID19.go.id/).

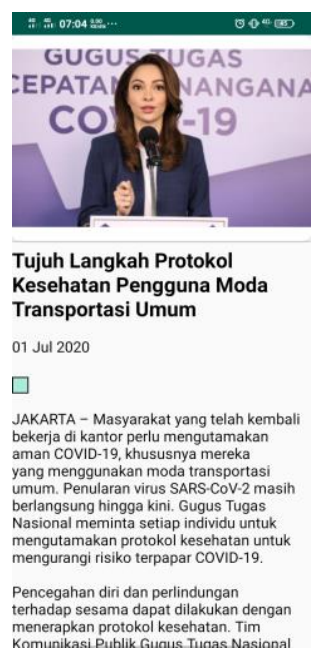

Gambar. 13.Tampilan informasi berita perkembangan COVID-19

Kemudian untuk menu early diagnosis yang berguna untuk memantau status kondisi karyawan mengenai gejala COVID-19. Gambar 14 merupakan contoh mengenai tampilan status kondisi kesehatan karyawan dari COVID-19. Selain menyediakan fitur diagnosis, di menu ini juga menyediakan fitur untuk melakukan sistem pakar. Terdapat beberapa pertanyaan yang harus dijawab oleh pengguna, pertanyaan-pertanyaan tersebut terdiri dari beberapa pertanyaan dengan pilihan jawaban dalam bentuk checklist yang masing-masing memiliki bobot jawaban. Bobot tersebut dijumlahkan dan dianalisa oleh sistem pakar sehingga dapat menghasilkan diagnosis berupa pengguna beresiko tinggi, sedang, atau beresiko rendah telah terjangkit virus COVID-19.

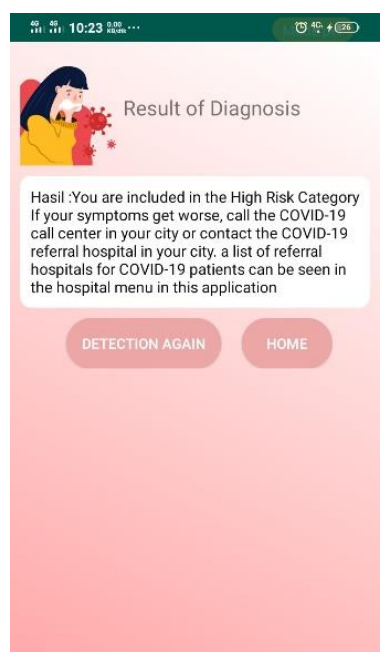

Gambar. 14.Tampilan hasil diagnosa dari sistem pakar

Pada aplikasi yang dibangun, terdapat pula fitur pilihan yang menampilkan data pasien COVID-19 di Indonesia 
beserta peta penyebarannya seperti terlihat pada gambar 15 . Pada peta sebaran sengaja ditampilkan dengan perbedaan warna mulai dari warna merah yaitu daerah dengan resiko tinggi, warna jingga yaitu daerah dengan resiko sedang, warna kuning yaitu daerah dengan resiko rendah, dan warna hijau yaitu artinya daerah tersebut belum terpengaruh COVID-19 [14].

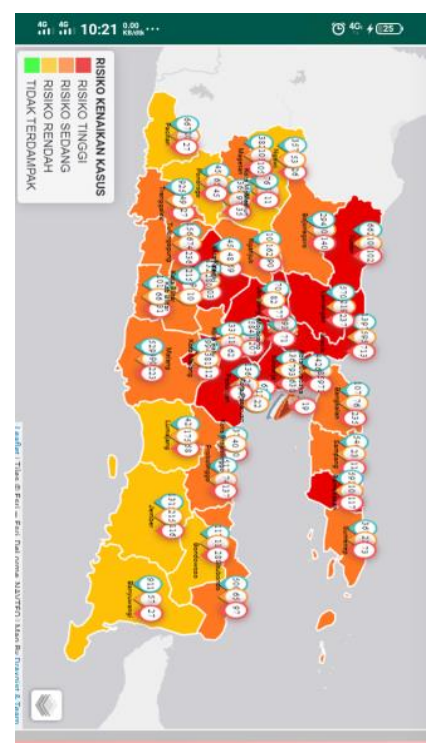

Gambar. 15.Tampilan hasil data penyebaran COID-19 dalam bentuk peta

\section{Pengujian terhadap tugas-tugas tertentu}

Untuk memeriksa sistem yang dibuat telah berjalan dengan baik atau tidak maka peneliti melakukan pengujian sistem dengan menggunakan pembuatan list tugas yang harus dilakukan oleh pengguna. Pembuatan tugas-tugas ini untuk melihat apakah fitur-fitur yang sudah dibuat sudah berjalan dengan baik atau belum. Tabel 3 menunjukkan pengujian dengan menggunakan metode skenario tugas, dimana terdapat 17 tugas yang harus dilakukan oleh pengguna untuk menguji keseluruhan sistem mulai dari perangkat keras (sistem monitoring suhu dan absensi) serta perangkat lunak (aplikasi server dan client).

\section{TABEL III. PENGUJIAN METODE SKENARIO TUGAS}

\begin{tabular}{|l|l|l|}
\hline Nomor & $\begin{array}{l}\text { Tugas } \\
\text { pengujian }\end{array}$ & $\begin{array}{l}\text { Penjelasan dari tugas pengujian yang } \\
\text { dilakukan }\end{array}$ \\
\hline \multicolumn{2}{|l|}{ Perangkat keras (sistem monitoring suhu dan absensi karyawan) } \\
\hline 1. & $\begin{array}{l}\text { Melakukan } \\
\text { Pengukuran } \\
\text { suhu }\end{array}$ & $\begin{array}{l}\text { Pengguna melakukan proses pengukuran } \\
\text { suhu melalui peralatan sensor suhu dengan } \\
\text { cara mendekatkan dahi pengguna ke sensor } \\
\text { dengan tidak menyentuh peralatan sensor }\end{array}$ \\
\hline 2. & $\begin{array}{l}\text { login kedalam } \\
\text { sistem absensi }\end{array}$ & $\begin{array}{l}\text { Setelah pengguna melakukan pengukuran } \\
\text { suhu, pengguna harus login ke sistem } \\
\text { absensi dengan menggunakan akun email } \\
\text { yang terdaftar pada sistem absensi }\end{array}$ \\
\hline 3. & $\begin{array}{l}\text { Menjawab } \\
\text { soal-soal yang } \\
\text { disediakan } \\
\text { sistem pakar }\end{array}$ & $\begin{array}{l}\text { Setelah pengguna melakukan login, } \\
\text { pengguna harus menjawab pertanyaan- } \\
\text { pertanyaan yang disediakan sistem pakar } \\
\text { untuk dijadikan parameter pengambilan } \\
\text { keputusan. }\end{array}$ \\
\hline 4. & $\begin{array}{l}\text { Memperoleh } \\
\text { hasil } \\
\text { diagnostik }\end{array}$ & $\begin{array}{l}\text { Setelah pengguna menyelesaikan pertanyaan } \\
\text { yang diberikan, pengguna harus menunggu } \\
\text { untuk hasil diagnostik dari jawaban yang } \\
\text { telah diberikan melalui sistem, untuk }\end{array}$ \\
\hline
\end{tabular}

\begin{tabular}{|c|c|c|}
\hline & & $\begin{array}{l}\text { mengetahu apakah pengguna telah berisiko } \\
\text { terinfeksi } C O V I D-19 \text { atau tidak. }\end{array}$ \\
\hline \multicolumn{3}{|c|}{ Perangkat keras (aolikasi disisi server dam aplikasi client) } \\
\hline 5. & $\begin{array}{l}\text { Halaman } \\
\text { utama }\end{array}$ & $\begin{array}{l}\text { Pengguna dapat mengakses halaman server } \\
\text { yang telah disediakan dengan domain } \\
\text { https://webdevelopervsga2020.000webhosta } \\
\text { pp.com/ }\end{array}$ \\
\hline 6. & $\begin{array}{l}\text { Login pada } \\
\text { aplikasi }\end{array}$ & $\begin{array}{l}\text { User melakukan login dengan akun email } \\
\text { yang terdaftar pada database sistem. Pada } \\
\text { halaman login terdapat } 3 \text { pilihan } \text { user yaitu } \\
\text { user admin, user dosen, dan user mahasiswa }\end{array}$ \\
\hline 7. & $\begin{array}{l}\text { Login } \\
\text { halaman } \\
\text { admin }\end{array}$ & $\begin{array}{l}\text { Setelah melakukan login, user admin bisa } \\
\text { mengakses halaman dashboard admin untuk } \\
\text { menampilkan beberapa navigasi sistem. }\end{array}$ \\
\hline 8. & $\begin{array}{l}\text { Melakukan } \\
\text { manipulasi } \\
\text { dan update } \\
\text { data }\end{array}$ & $\begin{array}{l}\text { Pengguna diharus bisa memanipulasi data } \\
\text { yang disediakan pada tabel berupa membaca, } \\
\text { memperbarui, membuat, dan menghapus } \\
\text { data }\end{array}$ \\
\hline 9. & Layanan web & $\begin{array}{l}\text { Pengguna bisa melihat layanan yang telah } \\
\text { disediakan oleh sistem berupa tabel yang } \\
\text { ditampilkan dalam bentuk data JSON }\end{array}$ \\
\hline 10. & Keluar & $\begin{array}{l}\text { Pengguna dapat melakukan perintah keluar } \\
\text { dari dashboard sistem admin }\end{array}$ \\
\hline 11. & $\begin{array}{l}\text { Halaman } \\
\text { utama }\end{array}$ & $\begin{array}{l}\text { Pengguna dapat melihat dan mencoba } 6 \\
\text { menu navigasi yang tersedia }\end{array}$ \\
\hline 12. & $\begin{array}{l}\text { data pasien } \\
\text { COVID-19 }\end{array}$ & $\begin{array}{l}\text { Pengguna dapat melihat data pasien COVID- } \\
19 \text { di Indonesia, baik yang dipastikan telah } \\
\text { sembuh, dan telah meninggal }\end{array}$ \\
\hline 13. & $\begin{array}{l}\text { Lihat berita } \\
\text { COVID-19 }\end{array}$ & $\begin{array}{l}\text { Pengguna dapat melihat halaman berita yang } \\
\text { terupdate pada setiap harinya }\end{array}$ \\
\hline 14. & $\begin{array}{l}\text { Lihat Peta } \\
\text { sebaran } \\
\text { COVD-19 }\end{array}$ & $\begin{array}{l}\text { Pengguna dapat melihat halaman peta } \\
\text { sebaran COVID-19 di Indonesia yang tersaji } \\
\text { dalam bentuk GIS }\end{array}$ \\
\hline 15. & Deteksi dini & $\begin{array}{l}\text { Pengguna dapat melakukan percobaan } \\
\text { deteksi dini COVID-19 dan mendapatkan } \\
\text { hasil diagnosis yang sesuai }\end{array}$ \\
\hline 16. & $\begin{array}{l}\text { Menampilkan } \\
\text { rumah sakit }\end{array}$ & $\begin{array}{l}\text { Pengguna dapat melihat daftar data rumah } \\
\text { sakit yang ditunjuk pemerintah sebagai } \\
\text { rumah sakit rujukan bagi pasien COVID-19 } \\
\text { di Indonesia }\end{array}$ \\
\hline 17. & $\begin{array}{l}\text { Keluar } \\
\text { aplikasi }\end{array}$ & $\begin{array}{l}\text { Pengguna dapat melakukan aksi keluar dari } \\
\text { aplikasi }\end{array}$ \\
\hline
\end{tabular}

Hasil uji coba dari tugas pengujian mulai dari nomo 1 hingga 17 dapat disimpulkan bahwa rata-rata dari hasil menunjukkan $100 \%$ smua fitur sudah dapat berjalan dengan baik. Proses pengujian ini dilakukan oleh semua user, baik user yang mempunyai peran sebagai admin, karyawan, maupun managerial.

\section{Pengujian dengan membuat pertanyaan mengenai pengalaman pengguna}

Pada tahap pengujian dengan menggunakan pertanyaan kepuasan pengguna ini adalah untuk mengetahui tingkat kemudahan, kenyamanan, kepuasan, dan kegunaan dari sistem yang sudah dibuat. Proses pengujian dengan metode ini caranya adalah dengan membagikan kertas kepada user yang terdapat pertanyaan-pertanyaan mengenai kemanfaatan sistem, kemudahan proses pembelajaran, dan kemudahan sistem bagi penggunaan. Untuk memenuhi data kuisioner dan agar hasilnya lebih valid, peneliti telah mengumpulkan sebanyak 3 kali data pengujian. Tabel 4 merupakan hasil kesimpulan yang telah di proleh oleh peneliti dari data yang 
Jurnal Teknologi Informasi dan Terapan (J-TIT) Vol. 8 No. 1 Juni 2021 ISSN: 2580-2291

dibagikan. Dimana dari pengambilan data sebanyak 3 kali dapat disimpulkan bahwa rata-rata kepuasan pengguna terhadap aplikasi ini adalah 95, 54 /100.

TABEL IV. KESIMPULAN DARI JAWABAN KUISIONER

\begin{tabular}{|c|c|c|}
\hline Nomor & Kategori pertanyaan user & $\begin{array}{l}\text { Rata-rata } \\
\text { jawaban }\end{array}$ \\
\hline \multicolumn{3}{|c|}{ Pengambilan pengujian pertama } \\
\hline 1. & $\begin{array}{l}\text { Persetujuan tentang kegunaan } \\
\text { aplikasi }\end{array}$ & $97 / 100$ \\
\hline 2. & $\begin{array}{l}\text { Persetujuan tentang } \\
\text { kemudahan bagi penggunaan }\end{array}$ & $95 / 100$ \\
\hline 3. & $\begin{array}{l}\text { Persetujuan tentang } \\
\text { kemudahan dalam belajar }\end{array}$ & $94 / 100$ \\
\hline 4. & $\begin{array}{l}\text { Persetujuan tentang kepuasan } \\
\text { pengguna }\end{array}$ & $94,5 / 100$ \\
\hline \multicolumn{2}{|c|}{ Rata-rata jawaban dari semua kategori } & $95,12 / 100$ \\
\hline \multicolumn{3}{|c|}{ Pengambilan pengujian kedua } \\
\hline 1. & $\begin{array}{l}\text { Persetujuan tentang kegunaan } \\
\text { aplikasi }\end{array}$ & $96,6 / 100$ \\
\hline 2. & $\begin{array}{lr}\text { Persetujuan } & \text { tentang } \\
\text { kemudahan bagi penggunaan }\end{array}$ & $95,6 / 100$ \\
\hline 3. & $\begin{array}{l}\text { Persetujuan tentang } \\
\text { kemudahan dalam belajar }\end{array}$ & $94 / 100$ \\
\hline 4. & $\begin{array}{l}\text { Persetujuan tentang kepuasan } \\
\text { pengguna }\end{array}$ & $95,2 / 100$ \\
\hline \multicolumn{2}{|c|}{ Rata-rata jawaban dari semua kategori } & $95,35 / 100$ \\
\hline \multicolumn{3}{|c|}{ Pengambilan pengujian ketiga } \\
\hline 1. & $\begin{array}{l}\text { Persetujuan tentang kegunaan } \\
\text { aplikasi }\end{array}$ & $97,3 / 100$ \\
\hline 2. & $\begin{array}{lr}\text { Persetujuan } & \text { tentang } \\
\text { kemudahan bagi penggunaan }\end{array}$ & $96,3 / 100$ \\
\hline 3. & $\begin{array}{l}\text { Persetujuan tentang } \\
\text { kemudahan dalam belajar }\end{array}$ & $95 / 100$ \\
\hline 4. & $\begin{array}{l}\text { Persetujuan tentang kepuasan } \\
\text { pengguna }\end{array}$ & $96 / 100$ \\
\hline \multicolumn{2}{|r|}{ a jawaban dari semua kategori } & $96,15 / 100$ \\
\hline
\end{tabular}

\section{E. Pengujian validasi terhadap sistem monitoring suhu}

Untuk mengetahui apakah sistem monitoring suhu yang telah dibuat sudah dapat mengambil data secara benar atau tidak. Maka pada penelitian ini dilakukan uji coba dengan membandingkan hasi pengambilan data suhu yang dilakukan oleh sistem yang dibuat dengan alat thermal gun yang sudah ada. Gambar 16 merupakan tampilan grafik yang menunjukkan hasil pengambilan data suhu 20 pengguna yang dilakukan dengan thermal gun dan sistem monitoring suhu yang dibuat dengan sensor MLX90614 pada penelitian ini. Dari grafik dapat disimpulkan bahwa eror ratio yang ditunjukkan dari proses pengambilan data sekitar 0.19 dari keseluruhan data. Adanya perbadaan eror ratio ini bisa disebabkan oleh beberapa faktor. Faktor yang dapat mempengaruhi perbedaan hasil antara sensor MLX90614 dan thermal gun adalah keakuratan dari jarak sensor ke objek yang dideteksi saat melakukan deteksi suhu.

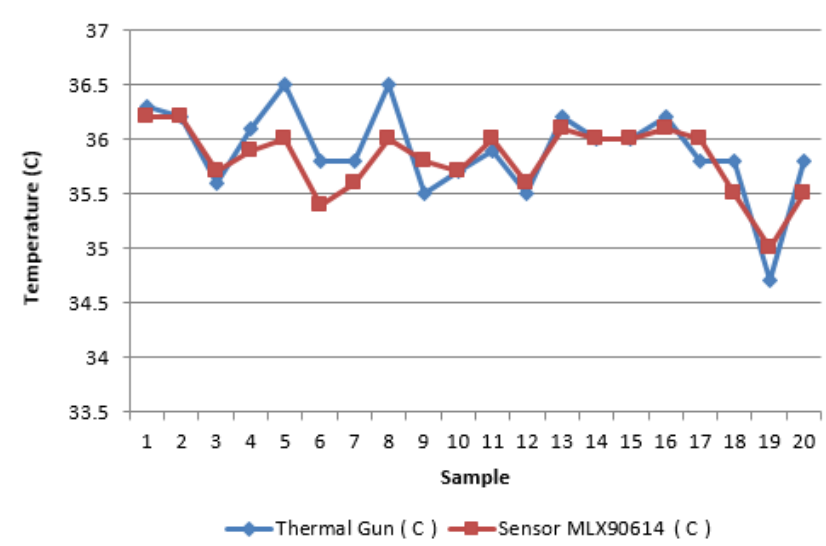

Gambar. 16.Grafik pengukuran suhu dari sistem dan thermal gun

\section{F. Analisa Kepakaran dan Perbandingan Sistem}

Agar kepakaran sistem lebih teruji, maka disini akan dilakukan pengujian terhadap setiap indikator pertanyaan dari sistem pakar yang disimbolkan mulai dari I1 sampai dengan I16 terhadap kesimpulan yang didapatkan dibandingkan dengan hasil sebenarnya. Tabel 5 menunjukkan hasil dari pengujian setiap indikator pertanyaan terhadap kondisi dari user apakah sesuai dengan hasil kondisi sebenarnya atau tidak.

TABEL V. ANALISA KEPAKARAN SISTEM

\begin{tabular}{|c|l|l|l|}
\hline $\begin{array}{c}\text { Jika menjawab } \\
\text { iya pada } \\
\text { indikator }\end{array}$ & $\begin{array}{c}\text { Jumlah } \\
\text { bobot }\end{array}$ & $\begin{array}{c}\text { Hasil yang } \\
\text { seharusnya terhadap } \\
\text { resiko COVID }\end{array}$ & $\begin{array}{c}\text { Apakah hasil } \\
\text { sesuai dengan } \\
\text { sebenarnya? }\end{array}$ \\
\hline $\begin{array}{c}\text { Salah satu dari } \\
\text { I1 sampai I8 }\end{array}$ & 6 & Akan beresiko tinggi & iya \\
\hline $\begin{array}{c}\text { Salah satu dari } \\
\text { I9 sampai I12 }\end{array}$ & 1 & Akan beresiko rendah & iya \\
\hline I9 dan I10 & 2 & Akan beresiko sedang & iya \\
\hline I11 dan 112 & 2 & Akan beresiko sedang & iya \\
\hline $\begin{array}{c}\text { I9, I10, I11, dan } \\
\text { I12 }\end{array}$ & 4 & Akan beresiko sedang & iya \\
\hline I9 dan I13 & 6 & Akan beresiko tinggi & iya \\
\hline I10 dan I14 & 6 & Akan beresiko tinggi & iya \\
\hline I11 dan I15 & 6 & Akan beresiko tinggi & iya \\
\hline $\begin{array}{c}\text { I9 dan I10, I11 } \\
\text { dan I14 }\end{array}$ & 8 & Akan beresiko tinggi & iya \\
\hline I16 & 0 & Akan beresiko rendah & iya \\
\hline
\end{tabular}

Sedangkan untuk menguji keunikan dari sistem serta kontribusi dari sistem, maka disini juga akan dilakukan perbandingan terhadap penelitian yang lain. Dimana penelitian ini akan dibandingkan dengan penelitian dari I. Sinuraya et al. [15] yang mengusulkan tentang pembuatan sistem pakar dalam bidang kedokteran yang lebih spesifik untuk digunakan dalam melakukan deteksi COVID-19 dengan metode Certainty Factor. Tabel 6 menunjukkan perbandingan antara penelitian sebelumnya dengan penelitian yang diusulkan, dimana yang dianalisa mulai dari judul, tahun, indikator gejala, dan hasi dari setiap penelitian. Dimana dari tabel dapat disimpulkan bahwa penelitian yang 
diusulkan memiliki hasil yang lebih spesifik karena lebih banyak gejala yang dianalisa, serta lebih mendapatkan hasil yang lebih akurat, dikarenakan banyak analisa yang dilakukan.

\section{TABEL VI. PERBANDINGAN PENELITIAN}

\begin{tabular}{|c|c|c|c|}
\hline $\begin{array}{c}\text { Judul } \\
\text { Penelitian }\end{array}$ & Tahun & Indikator gejala & Hasil penelitian \\
\hline $\begin{array}{c}\text { Covid-19 } \\
\text { Diagnosis } \\
\text { Based Android } \\
\text { Mobile } \\
\text { Application } \\
\text { using Certainty } \\
\text { Factor Method }\end{array}$ & 2020 & $\begin{array}{l}\text { Sakit } \\
\text { Tenggorokan, } \\
\text { Sesak Nafas, } \\
\text { Pilek, Batuk yang } \\
\text { berkelanjutan, } \\
\text { Demam, } \\
\text { Menggigil }\end{array}$ & $\begin{array}{ll}\text { - } & \text { Sistem mobile } \\
\text { - } & \text { Sistem web } \\
\text { - } & \text { Analisa nilai } \\
\text { kepercayaan } \\
\text { (MB), nilai tidak } \\
\text { kepercayaan } \\
\text { (MD), dan nilai } \\
\text { kepastian (CF) }\end{array}$ \\
\hline $\begin{array}{c}\text { Sistem } \\
\text { Monitoring } \\
\text { Suhu pada } \\
\text { Aplikasi } \\
\text { Absensi } \\
\text { Pegawai untuk } \\
\text { Deteksi Dini } \\
\text { COVID-19 } \\
\text { (yang } \\
\text { diusulkan) }\end{array}$ & 2021 & $\begin{array}{l}\text { Kesulitan } \\
\text { bernafas, dada } \\
\text { sakit, sulit } \\
\text { bangun, pusing, } \\
\text { hilang kesadaran, } \\
\text { nafas lebih } \\
\text { pendek, susah } \\
\text { berbaring, } \\
\text { kesehatan } \\
\text { memburuk, } \\
\text { demam, batuk, flu, } \\
\text { sakit tenggorokan, } \\
\text { gejala muncul } \\
\text { setelah bepergian, } \\
\text { pernah } \\
\text { bersentuhan } \\
\text { dengan pasien } \\
\text { COVID }\end{array}$ & $\begin{array}{ll}\text { - } & \text { Sistem mobile } \\
\text { - } & \text { Sistem web } \\
\text { - } & \text { Analisa } \\
\text { pengujian } \\
\text { dengan metode } \\
\text { skenario tugas } \\
\text { - Analisa } \\
\text { kuisioner } \\
\text { penggunaan } \\
\text { aplikasi } \\
\text { - Analisa validasi } \\
\text { sistem } \\
\text { - Analisa } \\
\text { kepakaran sistem }\end{array}$ \\
\hline
\end{tabular}

\section{KESIMPULAN}

Penemuan kasus COVID-19 yang terjadi di area perkantoran merupakan salah satu dari kasus yang paling banyak ditemukan di Indonesia. Meskipun sudah dibuat protocol kesehatan oleh pemerintah tetapi untuk hasilnya masih belum sesuai harapan. Proses untuk pencegahan yang efisien adalah dengan memastikan bahwa karyawankaryawan yang akan bekerja di kantor dipastikan dalam kondisi sehat. Pada penelitian ini bertujuan untuk membuat sebuah sistem monitoring suhu yang diterapka pada aplikasi absensi pegawai untuk melakukan deteksi dini COVID-19 pada pegawai-pegawai yang mengharuskan bekerja di kantor. Sistem aplikasi absensi pegawai yang diusulkan ini juga dilengkapi dengan sistem pakar yang mana deteksi suhu juga merupakan salah satu indikatornya. Hasil dari pembuatan sistem ini setelah dilakukan beberapa kali pengujian adalah didapatkan bahwa kepuasan pengguna terhadap sistem ini adalah $95.54 \%$. Sedangkan untuk pengujian kepakaran sistem telah menunjukkan hasil yang sesuai antara hasil yang diharapkan dengan kondisi yang sebenarnya. Dan untuk ketepatan dari sistem deteksi suhu dari sistem ini jika dibandingkan dengan termometer yang ada adalah mempunyai eror ratio 0.19. Sehingga untuk penelitian selanjutnya diharapkan bisa memperkecil dari eror ratio dari sistem deteksi suhu yang dilakukan.

\section{PENGHARGAAN}

Ucapan terima kasih peneliti sampaikan kepada institusi Politeknik Elektronika Negeri Surabaya telah menjadi sponsor dari penelitian lokal ini melalui pusat penelitian dan pengabdian masyarakat Politeknik Elektronika Negeri Surabaya.

\section{REFERENSI}

[1] Wiranti, A. Sriatmi, and W. Kusumastuti, "Determinan kepatuhan masyarakat Kota Depok terhadap kebijakan pembatasan sosial berskala besar dalam pencegahan COVID-19," J. Kebijak. Kesehat. Indones, vol. 09, no. 03, pp. 117-124, 2020.

[2] Emmanuel Abidemi Adeniyi, Joseph Bamidele Awotunde, Roseline Oluwaseun Ogundokun et al. "Mobile Health Application And COVID-19: Opportunities And Challenges," Journal of Critical Reviews, Vol. 7, No. 15, pp. 3481-3488, 2020.

[3] Ramadhan Tosepu, Joko Gunawan, Devi Savitri Effendy, Hariati Lestari, Hartati Bahar, Pitrah Asfian, "Correlation between Weather and COVID-19 pandemic in Jakarta, Indonesia," Science of The Total Environment, hlm. 138436, 2020.

[4] Yulianti Pratiwi Utami, Agung Triayudi, and Endah Tri Esthi Handayani, "Sistem Pakar Deteksi Penyakit Diabetes Mellitus (DM) menggunakan Metode Forward chaining dan Certainty factor Berbasis Android," Jurnal JTIK (Jurnal Teknologi Informasi dan Komunikasi), Vol. 5, No. 1, pp. 49-55, 2021.

[5] Prisa Marga Kusumantara, Nur Cahyo Wibowo, and Yesi Novia, "Pemodelan Basis Pengetahuan Untuk Diagnosis Covid-19 Dan Penyakit Lain Dengan Gejala Serupa," Jurnal Informatika dan Sistem Informasi (JIFoSI), Vol. 1, No. 3, pp. 946-952, 2020.

[6] David A. Drew, Long H. Nguyen, Claire J. Steves et al. "Rapid implementation of mobile technology for real-time epidemiology of COVID-19," Science, Vol. 368, No. 6497, pp. 1362-1367, 2020.

[7] Andrew Urbaczewski, and Young Jin Lee. "Information Technology And The Pandemic: A Preliminary Multinational Analysis Of The Impact Of Mobile Tracking Technology On The COVID-19 Contagion Control," European Journal of Information Systems, Vol. 29, No. 4, pp. 405-414, 2020.

[8] R. Vaishya, M. Javaid, I. H. Khan, and A. Haleem, "Artificial Intelligence (AI) applications for COVID-19 pandemic," Diabetes Metab. Syndr. Clin. Res. Rev., vol. 14, no. 4, pp. 337-339, 2020.

[9] W. Arshad et al., "Informatics in Medicine Unlocked COVIDC : An expert system to diagnose COVID-19 and predict its severity using chest CT scans : Application in radiology," Informatics Med. Unlocked, vol. 23, p. 100540, 2021.

[10] R. Pratap, M. Javaid, A. Haleem, and R. Suman, "Internet of things (IoT) applications to fight against COVID-19 pandemic,” Diabetes \& Metabolic Syndrome: Clinical Research \& Reviews, vol. 14, no. 4, pp. 521-524, 2020.

[11] M. N. Mohammed, H. Syamsudin, S. Al-Zubaidi, A. K. Sairah, R. Ramli, and E. Yusuf, "Novel covid-19 detection and diagnosis system using iot based smart helmet," Int. J. Psychosoc. Rehabil., vol. 24, no. 7, pp. 2296-2303, 2020.

[12] Khusnul Khotimah, Mohammad Robihul Mufid, Arif Basofi, Saniyatul Mawaddah, Nurul Fuad, "Sistem Diagnosis dan Mitigasi Risiko COVID-19 Menggunakan Sistem Pakar dan Web Scraping", International Electronics Symposium (IES), pp. 577 - 583, 2020.

[13] M. R. Mufid, A. Basofi, I. Syarif, F. Sanjaya, "Estimated Vehicle Fuel Calculation Based on Google Map Realtime Distance," International Electronics Symposium (IES), pp. 354-358, 2019.

[14] M. R. Mufid, N. R. K. S. Putri, A. Fariza, "Fuzzy Logic and Exponential Smoothing for Mapping Implementation of Dengue Haemorrhagic Fever in Surabaya," International Electronics Symposium on Knowledge Creation and Intelligent Computing (IESKCIC), pp. 372-377, 2018.

[15] I. Sinuraya, A. Triayudi, and I. D. Sholihati, "Covid-19 Diagnosis Based Android Mobile Application using Certainty Factor Method," SISFOTENIKA. Vol. 10, No. 2, PP. 203-213, 2020. 